Sylwia Łazuk ${ }^{1}$

http://dx.doi.org/10.18778/8088-306.2.08

\title{
Zatrudnianie członków zarządu w spółce kapitałowej na podstawie wyboru
}

\section{Uwagi ogólne}

Problematyka związana z zatrudnieniem członków zarządu w spółkach kapitałowych wzbudza wiele niejasności. Jest to związane przede wszystkim z fragmentarycznością regulacji prawnych dotyczących relacji między spółkami a członkami ich organów. W kodeksie spółek handlowych ${ }^{2}$ nie ma unormowań, które w sposób jednoznaczny określałyby, na jakich zasadach ma być zatrudniony członek zarządu. Artykuł $203 \S 1$ k.s.h. oraz art. $370 \S 1$ k.s.h. stanowią wyłącznie, że odwołanie członka zarządu nie pozbawia go roszczeń ze stosunku pracy lub innego stosunku prawnego dotyczącego pełnienia funkcji członka zarządu. Ustawodawca sankcjonuje stanowisko, zgodnie z którym członek zarządu może świadczyć pracę na rzecz spółki na podstawie dodatkowych - obok aktu powołania - stosunków pracowniczych i niepracowniczych ${ }^{3}$. Dlatego też, rozważenia wymaga kwestia, która z podstaw prawnych zatrudnienia pracowników określona $\mathrm{w}$ art. 2 kodeksu pracy ${ }^{4}$ może stać się podstawą nawiązania stosunku pracy z członkami zarządu.

Już na początku należy wskazać regulacje zawarte w art. 197 $\S 1$ i art. 368 nieobowiązującego już Kodeksu handlowego ${ }^{5}$, które dawały możliwość odwołania członka zarządu w każdej chwili, co uwłaczało jego roszczeniom z umowy o pracę. Wspomniane przepisy zostały poddane szerokiej analizie przedstawicieli doktryny, jak też judykatury. Brak kompleksowej i wyczerpującej regulacji w kwestii zatrudnienia członków zarządu wymagał poszukiwania w przepisach pozakodeksowych ${ }^{6}$. Wśród nich należy wskazać prawo wewnętrzne spółki.

\footnotetext{
1 Doktorantka, Uniwersytet w Białymstoku, Wydział Prawa, Zakład Prawa Ochrony Środowiska i Nauki Administracji Publicznej. Aplikantka radcowska, Okręgowa Izba Radców Prawnych w Białymstoku.

2 Ustawa z dnia 15 września 2000 r., t.j., Dz.U. z 2013 r., poz. 1030 ze zm., dalej jako: k.s.h.

${ }^{3}$ A. Giedrewicz, Wybór jako podstawa nawiq̨zania stosunku pracy z członkami zarzq̨du spółek kapitałowych, „Monitor Prawniczy", nr 14/2014, s. 641.

${ }^{4}$ Ustawa z dnia 26 czerwca 1974 r., t.j., Dz.U. z 2014 r., poz. 1502 ze zm., dalej jako: k.p.

${ }^{5}$ Rozporządzenie Prezydenta Rzeczypospolitej z dnia 27 czerwca 1934 r., ustawa obowiązywała do 31 grudnia $2001 \mathrm{r}$.

${ }^{6}$ A. Giedrewicz, Wybór jako podstawa nawiązania..., s. 641.
} 
Możliwość takiej regulacji została określona w przepisach art. 197 § 1 i art. $368^{3}$ Kodeksu handlowego, w myśl których odwołanie członka zarządu nie pozbawia go roszczeń z umowy o pracę. Nowy kodeks spółek handlowych, odpowiednio w art. $203 \S 1$ i art. $370 \S 1$, rozbudował treść regulacji Kodeksu handlowego, stanowiąc, że odwołanie członka zarządu nie pozbawia go roszczeń ze stosunku prawnego dotyczącego pełnienia funkcji członka zarządu. Wynika z tego, że członek zarządu może zostać zatrudniony albo $\mathrm{w}$ ramach stosunku pracy albo $\mathrm{w}$ ramach niepracowniczych stosunków zatrudnienia. W związku z tym, rolą prawa wewnętrznego spółki jest określenie podstawy prawnej pełnienia funkcji zarządcy w spółkach kapitałowych. Należy jednak podkreślić, że możliwość zastosowania konkretnej podstawy zatrudnienia jest ograniczona regulacją zawartą w powszechnie obowiązujących przepisach rangi ustawowej ${ }^{7}$.

W opracowaniu zostanie przedstawiona istota wyboru, jak również zatrudnienie członków zarządu na podstawie wyboru oraz rozwiązanie stosunku pracy członków zarządu zatrudnionych w tenże sposób. W pracy zostanie podjęta również próba oceny, zarówno obecnego stanu prawnego regulującego tą materię, jak też kwestii tego, czy zatrudnianie członków zarządu w spółce kapitałowej na postawie wyboru jest dla nich korzystne czy nie.

\section{Wybór}

Regulacja kodeksu pracy w zakresie stosunku pracy z wyboru nie jest rozbudowana ${ }^{8}$. Zgodnie z art. 18 § 1 k.p., wybór jest innym niż umowa o pracę aktem, na podstawie którego powstaje stosunek pracy. Ponadto, w świetle przepisów kodeksu pracy, akt wyboru jest aktem jednostronnym, który dla swojej skuteczności, zgodnie z art. 11 k.p., wymaga zgody kandydata na pracownika. Dlatego też, wywołuje podwójny skutek: powierzenie określonej funkcji oraz nawiązanie stosunku pracy ${ }^{9}$. Pojęcie wyboru na gruncie prawa pracy jest ściśle związane ze świadczeniem pracy $\mathrm{w}$ charakterze pracownika. W doktrynie przyjmuje się, że wybór nie jest aktem zobowiązującym do nawiązania stosunku pracy, lecz bezpośrednio kreującym stosunek pracy ${ }^{10}$.

\footnotetext{
7 P. Skorupa, Podstawy prawne zatrudnienia członków zarządu w spółkach kapitałowych, „Prawo spółek”, nr 5/1998, s. 18.

8 A. Nowak, Ograniczenie możliwości zachowania lub odzyskania miejsca pracy przez członka zarzq̨du, „Z problematyki prawa pracy i polityki społecznej”, t. 16, Katowice 2005, s. 7.

${ }^{9}$ A. Reda, Zatrudnienie członka zarzq̨du spółki kapitałowej na podstawie stosunku pracy $z$ wyboru, „Praca i Zabezpieczenie Społeczne”, nr 7/2007, s. 27.

10 W. Sanetra, [w:] W. Sanetra, J. Iwulski, Kodeks pracy. Komentarz, Warszawa 2003, s. 290.
} 
Jak już zostało wspomniane, wybór jest najmniej omówioną w literaturze podstawą nawiązania stosunku pracy z członkami zarządu. Kodeks pracy stanowi, że nawiązanie stosunku pracy następuje na podstawie wyboru, jeżeli z wyboru wynika obowiązek pracy w charakterze pracownika (art. 73 k.p.). Sprawowanie funkcji z wyboru stanowi, na gruncie prawa pracy istotę mandatu. Z kolei stosunek pracy z wyboru, z godnie z art. 73 § 2 k.p. rozwiązuje się z wygaśnięciem mandatu. Wynika z tego, że stosunek pracy z wyboru nie ma charakteru samodzielnego. Jego nawiązanie i rozwiązanie, w rozumieniu przepisów kodeksu pracy związane jest odpowiednio z uzyskaniem lub wygaśnięciem mandatu. Pozwala to na korzystne dostosowanie okresu trwania stosunku pracy do pełnienia funkcji z wyboru. Pojęciem mandatu posługuje się również kodeks spółek handlowych. Mimo to, pojęcie mandatu nie doczekało się definicji legalnej i w zależności od dziedziny prawa kształtowane jest przez doktrynę i judykaturę. W kodeksie pracy mandat, o którym mowa w art. $73 \S 2$ k.p. oznacza pełnomocnictwo do pełnienia określonej funkcji powierzonej w drodze wyboru, zaś w prawie handlowym wymienione są jedynie zdarzenia prowadzące do wygaśnięcie mandatu. Niemniej jednak, wydaje się, że mandat na gruncie kodeksu spółek handlowych można rozumieć jako umocowanie danej osoby do sprawowania określonej funkcji11. W związku z tym, obydwa rozumienia pojęcia mandat można uznać za tożsame i tak też uznaje większość przedstawicieli doktryny ${ }^{12}$. Z kolei Ł. Pisarczyk nie zgadza się z tym poglądem i stoi na stanowisku, iż mandat na gruncie kodeksu prawa handlowego należy traktować jako więź organizacyjną łączącą członka zarządu ze spółką. która zobowiązuje go do rozliczenia się ze sprawowania swojej funkcji przed zwyczajnym zgromadzeniem. Dlatego też, istotą mandatu jest w tym ujęciu nie samo sprawowanie funkcji, lecz obowiązek rozliczenia się ze spółką ${ }^{13}$.

Podstawowym zagadnieniem pozostaje możliwość zatrudnienia na podstawie wyboru członków zarządu spółki kapitałowej. Regulacja zawarta w kodeksie pracy nie jest wystarczająca do rozstrzygnięcia tego problemu. Kodeks pracy nie określa, kiedy i na jakich stanowiskach następuje pełnienie funkcji z wyboru w ramach stosunku pracy oraz czy z aktem wyboru wiąże się obowiązek świadczenia przez członka zarządu pracy w charakterze pracownika, a także jaki jest tryb dokonania wyboru i organ do tego uprawniony ${ }^{14}$. Rozstrzygnięcia tych

\footnotetext{
11 M. Tarska, Kodeks spółek handlowych. Komentarz, Warszawa 2002, s. 149.

12 Ibidem.

13 七. Pisarczyk, Podstawy nawiq̨zania stosunku pracy z członkiem zarzq̨du spółki kapitałowej, „Praca i Zabezpieczenie Społeczne”, nr 10/1998, s. 23.

${ }^{14}$ A. Giedrewicz, Wybór jako podstawa nawiq̨zania..., s. 642.
} 
kwestii, w przypadku członków zarządu, należy poszukiwać w kodeksie spółek handlowych oraz w statucie i umowie spółki z ograniczoną odpowiedzialnością. Ustawodawca w kodeksie spółek handlowych nie wypowiedział się wprost co do możliwości zatrudnienia w drodze wyboru członków zarządu ${ }^{15}$. Artykuł $203 \S 1$ k.s.h. i art. $370 \S 1$ k.s.h. stanowią, w sposób ogólnikowy, że odwołanie członka zarządu nie pozbawia go roszczeń ze stosunku pracy lub innego stosunku prawnego dotyczącego pełnienia funkcji członka zarządu. Stąd też rozstrzygnięcie zagadnienia zatrudnienia w drodze wyboru członków zarządu wymaga zwrócenia szczególnej uwagi na postanowienia prawa wewnętrznego spółki, tj. statutu i umowy spółki z ograniczoną odpowiedzialnością.

\section{Zatrudnienie członków zarządu}

W myśl art. 201 § 4 i art. 368 § 4 k.s.h. członków zarządu powołuje i odwołuje odpowiednio zgromadzenie wspólników (w spółce z ograniczoną odpowiedzialności) lub rada nadzorcza (w spółce akcyjnej), chyba że umowa spółki (statut) stanowi inaczej. Jednak ustawodawca nie wspomina we wskazanych przepisach o wyborze członków do zarządu. Jedynie orzeczenie dopuszczające wybór jako podstawę zatrudnienia członków zarządu oparto na regulacji Kodeksu handlowego sprzed nowelizacji, gdzie w art. $366 \S 3$ Kodeksu handlowego posłużono się słowem „wybór” na określenie sposobu objęcia funkcji członka zarządu ${ }^{16}$. Dlatego też przedstawiciele doktryny zastanawiają się, czy brak wyrażenia „wybiera” w regulacji kodeksu spółek handlowych oznacza nieistnienie w spółkach kapitałowych aktu wyboru w rozumieniu dotychczasowym tego terminu, tj. jako powierzenia określonej osobie funkcji członka zarządu. Takie stanowisko zyskało aprobatę w środowisku naukowym ${ }^{17}$, a konsekwencją takiej interpretacji byłoby stwierdzenie, że wybór nie może być podstawą nawiązania stosunku pracy z członkami zarządu, ponieważ nie istnieje jeden $\mathrm{z}$ dwóch koniecznych warunków stosowania tej instytucji.

Kodeks spółek handlowych posługuje się pojęciem „powołanie” dla określenia aktu, na podstawie którego następuje powierzenie funkcji członka zarządu spółki kapitałowej ${ }^{18}$. Zatem zgodnie z regulacją ko-

\footnotetext{
15 Ibidem.

16 Wyrok Sądu Apelacyjnego w Rzeszowie z dnia 4 sierpnia1994 r., III APr 8/94, OSA nr 1/1995, poz. 8.

17 M. Gersdorf, Zwiq̨zki prawa handlowego i prawa pracy w orzecznictwie Sq̨du Najwyższego, „Przegląd Prawa Handlowego”, nr 7/1999, s. 6.

${ }^{18}$ A. Reda, Zatrudnienie członka zarzq̨du spółki kapitałowej..., s. 27.
} 
deksu spółek handlowych, członek zarządu zostaje powołany do pełnienia swojej funkcji na pewien okres, który zwany jest kadencją. Ustawodawca nie wprowadza ograniczeń w odniesieniu do kadencji członka zarządu spółki z ograniczoną odpowiedzialnością. W przypadku, gdy umowa spółki z ograniczoną odpowiedzialnością nie stanowi inaczej, zarząd powoływany jest na okres jednego roku i zgodnie $\mathrm{z}$ art. $202 \S 1$ k.s.h., jego mandat wygasa $\mathrm{z}$ dniem odbycia zgromadzenia wspólników zatwierdzającego sprawozdanie finansowe za pierwszy pełny rok obrotowy. Wskazuje się także, że nie ma przeszkód, aby powołać członka zarządu za czas nieoznaczony19. W takiej sytuacji mandat wygasa z dniem odbycia się zgromadzenia wspólników zatwierdzającego sprawozdanie finansowe za ostatni rok obrotowy pełnienia funkcji. Z kolei w przypadku kadencji członka zarządu spółki akcyjnej, zgodnie z art. 369 § 1 i $§ 4$ k.s.h., okres sprawowania kadencji nie może być dłuższy niż pięć lat, a mandat członka zarządu wygasa najpóźniej z dniem odbycia się walnego zgromadzenia zatwierdzającego sprawozdanie finansowe za ostatni pełny rok obrotowy pełnienia funkcji członka zarządu. Nie ma za to przeszkód, aby ta sama osoba została ponownie powołana do zarządu, jednak z zastrzeżeniem, że nie może to być okres dłuższy niż pięć lat. Warto wskazać, iż ustawodawca w obydwu przypadkach w kodeksie spółek handlowych posługuje się pojęciem „powołanie” członka zarządu, a nie „wybór”. Z kolei w nieobowiązującym już Kodeksie handlowym odnaleźć można było takie terminy jak „ustanowienie” członka zarządu spółki z ograniczoną odpowiedzialnością (art. 195 § 3) oraz „wybór” członka zarządu spółki akcyjnej (art. 366 § 3). Obecna regulacja stanowi natomiast o „powołaniu” i „odwołaniu" członka zarządu ${ }^{20}$. Przedstawiciele doktryny wskazują, że nie należy jednak sądzić, iż użyte w przepisach kodeksu spółek handlowych określenie powołania oznacza powołanie w rozumieniu art. 68 k.p., czyli akt będący źródłem nawiązania stosunku pracy. Jest zbieżność terminów, a nie pojęcie to tożsame z powołaniem $\mathrm{w}$ rozumieniu art. 68 k.p. ${ }^{21}$ Sąd Najwyższy w wyroku z dnia 28 lipca 1999 r. ${ }^{22}$ wskazał, że samo powołanie członka zarządu spółki przez właściwy organ spółki nie oznacza nawiązania stosunku pracy, lecz oznacza powierze-

\footnotetext{
${ }_{19}$ R. Adamus, Problem dopuszczalności powołania członka zarzq̨du spółki z.o.o. na czas nieokreślony, „Monitor Prawniczy”, nr 12/2005, s. 583.

20 Zgodnie z art. $201 \S 3$ i $§ 4$ k.s.h. oraz art. 368 § 4 k.s.h.

${ }^{21}$ A. Reda, Zatrudnienie członka zarzq̨du spółki kapitałowej..., s. 28.

22 Wyrok Sądu Najwyższego z dnia 28 lipca 1999 r., I PKN 171/99, „,Monitor Prawniczy” nr $1 / 2000$, s. 3.
} 
nie określonej osobie funkcji członka organu osoby prawnej. Sąd Najwyższy w wyroku zauważył, że ustawodawca posługuje się terminem „powołanie” w przepisach prawa w sposób dosyć chaotyczny. Mianowicie zdarza się, że ustawodawca w przepisach prawa posługuje się pojęciem powołanie, a w rzeczywistości przepisy nie dotyczą nawiązania stosunku pracy albo odnoszą się do innej podstawy niż powołanie.

Zgodnie z przeważającym w literaturze poglądem, wybór na stanowisko powinien być dokonany przez organ kolegialny lub przez zespół ludzi, którzy nie stanowią organu ${ }^{23}$. Dlatego też wybierającym nie może być pojedyncza osoba. Wskazane stanowisko wykazuje jednak pewne mankamenty. Dotyczy to sytuacji, w której przepisy statutu lub umowy spółki z ograniczoną odpowiedzialnością wyraźnie przewidują wybór członka zarządu przez pojedynczą osobę. Takie postanowienie aktu wewnętrznego spółki należy uznać za ważne, zwłaszcza, że kodeks pracy nie reguluje kwestii podmiotów uprawnionych do dokonania wyboru 24 .

W doktrynie prawa pracy przyjmowano, że wyboru dokonuje się w drodze pisemnej25. Ustawodawca w art. $29 \S 5$ k.p. potwierdził te stanowisko stanowiąc, że przepisy art. 29 § 1-4 k.p. stosuje się odpowiednio do pozaumownych stosunków pracy. Dlatego też, zgodnie z art. $29 \S 2$ k.p. akt wyboru powinien być sporządzony na piśmie. Niezachowanie formy pisemnej aktu wyboru zobowiązuje pracodawcę do potwierdzenia pracownikowi - najpóźniej w dniu rozpoczęcia pracy ustalenia co do rodzaju wyboru i warunków zatrudnienia wskazanych w art. $29 \S 5$ k.p.

Akt wyboru powinien określać:

- rodzaj pracy,

- miejsce wykonywania pracy

- wynagrodzenie za pracę odpowiadające rodzajowi pracy, ze wskazaniem składników wynagrodzenia,

- wymiar czasu pracy,

- termin rozpoczęcia pracy ${ }^{26}$.

23 T. Zieliński, Prawo pracy. Zarys systemu, cz. 2, Prawo stosunku pracy, Warszawa-Kraków 1986, s. 29.

24 A. Giedrewicz, Wybór jako podstawa nawiq̨zania..., s. 644.

25 L. Kaczyński, Glosa do wyroku Sądu Najwyższego z dnia 11.06.1997 r., OSP nr 12/1998, poz. 206, s. 591.

26 Z. Góral, Swoistości stosunków pracy pracowników samorządowych, [w:] Z. Kubot, Szczególne formy zatrudnienia, Wrocław 2000, s. 120. 
Poza tym, pracodawca powinien poinformować pracownika na piśmie o warunkach zatrudnienia wskazanych w art. $29 \S 3$ k.p. Ponadto, jak wskazał Sąd Najwyższy w wyroku z dnia 4 grudnia 1979 r. ${ }^{27}$, jeżeli określona osoba została wybrana do pełnienia funkcji i ma wykonywać w charakterze pracownika obowiązki wynikające z pełnionej funkcji, to stosunek pracy obejmujący wskazane obowiązki jest stosunkiem pracy z wyboru, nawet mimo tego, że zatrudnienie mandatariusza nie nastąpiłoby niezwłocznie po wyborze, lecz w późniejszym terminie.

\section{Rozwiązanie stosunku pracy $\mathrm{z}$ wyboru}

Na gruncie obowiązującego stanu prawnego powstaje zasadnicza wątpliwość co do tego, czy unormowania zawarte w art. 73-75 k.p., a dotyczące rozwiązania stosunku pracy z wyboru, mają charakter wyczerpujący i samodzielny, czy też ewentualnie istnieje możliwość odpowiedniego wykorzystania przepisów regulujących rozwiązanie umowy o pracę. W nauce prawa ukształtował się pogląd, iż brak wyraźnego odesłania do przepisów o rozwiązaniu umów o pracę, odpowiadającego treści art. 69 k.p., wyklucza możliwość ich odpowiedniego stosowania do ustania stosunku pracy z wyboru ${ }^{28}$. Oznacza to, iż stosunek pracy z wyboru nie może ulec rozwiązaniu ani za wypowiedzeniem, ani bez wypowiedzenia czy też za porozumieniem stron. Do takiego stanowiska przychylił się także Sąd Najwyższy w cytowanym już wyroku z dnia 4 grudnia 1979 r. wskazując, iż art. 73 § 2 k.p. w sposób wyczerpujący i samodzielny reguluje kwestie rozwiązania stosunku pracy $\mathrm{z}$ wyboru. Sąd ten wychodząc z powyższego założenia, odmówił pracownikom, z którymi w sposób niezgodny z prawem rozwiązano stosunek pracy z wyboru, prawa do dochodzenia roszczeń, jakie przysługują w razie wadliwego rozwiązania umowy o pracę.

Jednak Sąd Najwyższy zmienił dotychczasową linię orzecznictwa w latach dziewięćdziesiątych, skłaniając się do przyznania tej grupie pracowników - w sytuacji ich niezgodnego z prawem odwołania roszczeń właściwych dla umownego stosunku pracy. Z racji tego, że brakuje orzecznictwa związanego $\mathrm{z}$ roszczeniami pracowniczymi członków zarządu spółek kapitałowych, powołam się na przykład

\footnotetext{
27 Wyrok Sądu Najwyższego z dnia 4 grudnia 1979 r., I PR 93/79, OSN nr 6/1980, poz. 122.

28 Z. Kubot, Status pracowniczy członków zarządu spółki kapitałowej, „Praca i Zabezpieczenie Społeczne", nr 3/1993, s.35.
} 
członków zarządu gminy. W uchwale z dnia 8 grudnia 1995 r. ${ }^{29}$ Sąd Najwyższy uznał, że zatrudnionemu na podstawie wyboru członkowi zarządu gminy, odwołanemu z zajmowanego stanowiska z naruszeniem przepisów ustawowych oraz postanowień statutu gminy, przysługują roszczenia przewidziane w art. 56 i 59 k.p., co oznacza, iż może on domagać się zarówno odszkodowania, jak i przywrócenia do pracy.

Brak analogicznego unormowania w ustawowych przepisach dotyczących członków zarządu spółek kapitałowych może budzić wątpliwości co do ewentualnego przyznania tej kategorii osób zarządzających - w sytuacji wadliwego odwołania ze stanowiska - roszczeń, jakie przysługują $\mathrm{w}$ razie niezgodnego $\mathrm{z}$ prawem rozwiązania umowy o pracę. Uważam, iż zasada uprzywilejowania pracowników obowiązująca w ustawodawstwie pracy oraz pewne podobieństwa, jakie zachodzą pomiędzy stosunkiem pracy z wyboru i umową o pracę na czas określony mogłyby co najwyżej uzasadniać przyznanie członkowi zarządu zatrudnionemu na podstawie wyboru roszczenia o odszkodowanie. Takie bowiem roszczenie przysługuje członkowi zarządu, z którym wadliwie rozwiązano bez wypowiedzenia umowę na czas określony.

Niezależnie od tego, członkowie zarządu, których odwołanie nastąpiło z naruszeniem prawa, wskutek czego doszło do rozwiązania stosunku pracy z wyboru, mogą temu przeciwdziałać przy wykorzystaniu środków przewidzianych w kodeksie spółek handlowych. Przykładowo, członek zarządu będący jednocześnie wspólnikiem spółki z o.o. może zaskarżyć uchwałę zgromadzenia wspólników o jego odwołaniu podjętą sprzecznie z umową spółki w drodze powództwa wytoczonego przeciwko spółce o uchylenie uchwały na zasadach określonych w art. 249-251 k.s.h. W przypadku zaś, gdy uchwała ta była sprzeczna z kodeksem spółek handlowych, byłemu członkowi zarządu - wspólnikowi przysługuje prawo do wytoczenia przeciwko spółce powództwa o stwierdzenie nieważności tej uchwały (art. 252 k.s.h.).

\section{Podsumowanie}

Podsumowując, kwestia zatrudnienia członków zarządu w spółce kapitałowej na podstawie wyboru nie jest uregulowane w sposób kompleksowy w jednym akcie prawnym, a więc wymaga korzystania $\mathrm{z}$ różnych regulacji. 0 tym, czy podstawą nawiązania stosunku pracy z członkiem zarządu jest wybór decydują postanowienia umowne spółki z ograniczoną odpowiedzialnością lub statutu spółki

29 Uchwała Sądu Najwyższego z dnia 8 grudnia 1995 r., I PZP 50/94, OSNAPiUS nr 10/1995, poz.120. 
akcyjnej. Mimo to regulacje prawa wewnętrznego spółki nie mogą inaczej normować przesłanek i skutków nawiązania stosunku pracy z wyboru niż czynią to przepisy rangi ustawowej.

Moim zdaniem należy postulować, aby odrębności dotyczące nawiązania i rozwiązania stosunku pracy z wyboru były dostrzegane przez ustawodawcę i wyrażone w bardziej rozbudowanych rozwiązaniach normatywnych. Natomiast, jeżeli chodzi o kwestię korzystności tej formy zatrudnienia członków zarządu spółek kapitałowych, to uważam, iż jest to najbardziej preferowana forma zatrudnienia przede wszystkim dlatego, że nie zależy od wyników i pracy konkretnego członka zarządu, a od samego faktu podjęcia przez pracownika konkretnej funkcji. 